DOI

\title{
ГІГІЄНІЧНІ АСПЕКТИ ПРОФЕСІЙНОГО СТАНОВЛЕННЯ ТА ЕФЕКТИВНОЇ ПРАКТИЧНОЇ ДІЯЛЬНОСТІ ЛІКАРЯ-СТОМАТОЛОГА
}

Л. М. Ваколюк

Вінницький національний медичний університет імені М. I. Пирогова

\section{HYGIENIC ASPECTS OF PROFESSIONAL DEVELOPMENT AND EFFECTIVE PRACTICE ACTIVITY OF A DENTIST}

\section{M. Vakolyuk}

\author{
Vinnytsia National Medical University by M. I. Pyrohov
}

\begin{abstract}
У статті висвітлено методичні аспекти викладання профілактичної медицини для майбутніх лікарів-стоматологів. Предмет закладає основи вивчення студентами факторів навколишнього середовища i їх впливу на загальне та стоматологічне здоров'я, відкриває можливості для формування у студентів-стоматологів профілактичного мислення, спрямованого на збереження і зміцнення загального та стоматологічного здоров’я.
\end{abstract}

The article adduces the methodological aspects to the teaching of Prophylactic Medicine for future dentists. The subject lays the foundation for the study of environmental factors and their influence on general and dental health, provides opportunities for the formation of dental students prophylactic thinking, direct at the preservation and promotion of general and dental health.

Вступ. Сьогоднішні умови вимагають підготовки висококваліфікованих лікарів-стоматологів. Для вітчизняної охорони здоров’я найбільш характерним стало зростання кількості стоматологів та стоматологічних кабінетів, впровадження нових стоматологічних технологій. Сучасна підготовка лікаря стоматологічного профілю має на меті сформувати фахівця, який вміє органічно поєднувати теоретичні знання та практичні навички як у галузі клінічної, так і в галузі профілактичної медицини [1]. Тому медична освіта незалежно від її характеру, рівня та спрямування в обов’язковому порядку повинна сприяти формуванню у молодого спеціаліста гігієнічного мислення, розуміння ролі чинників навколишнього середовища та соціальних умов життя у виникненні різноманітних зрушень у стані здоров'я та захворювань, уміння адекватно визначати та запроваджувати у повсякденне життя різноманітні заходи профілактики. Враховуючи ситуацію в країні, профілактичні заходи будуть економічно вигідними для населення. Лікар орієнтований на нездоров’я і корекцію хворого організму перш за все або виключно за допомогою медикаментозних заходів. Профілактичний та оздоровчий рівні у нас у країні не виконуються. Дещо кращою є ситуація у розвинутих

(с) Л. М. Ваколюк країнах. Причини непрофілактичної спрямованості вітчизняної медицини:

1. Навчання проводиться на базі клінічних лікарень, де показовими пацієнтами є важкохворі.

2. Студента не навчають методик формування профілактичної свідомості у пацієнтів.

3. Недостатня кількість часу, що може присвятити лікар одному пацієнту.

4. Економічна незацікавленість (основна задача сучасного лікаря - перевести гострий біль у хронічний).

5. Зацікавленість фармацевтичних фірм у виробленні та реалізації ліків.

6. Загальна непрофілактична спрямованість суспільної ментальності.

Однак однією з необхідностей сьогодення $€$ збереження та збільшення ресурсів здоров’я населення.

Основна частина. У нових умовах демократизації українського суспільства, коли роль самостійної творчої людини гостро зростає, орієнтація на формування висококваліфікованого спеціаліста стає головним напрямом перебудови освіти на якісно новій основі [2]. Навчальні програми з загальної гігієни та екології людини для студентів стоматологічних факультетів зумовлюють потребу у забезпеченні студентів сучасною навчальною літературою, подальшому розвиткові їх профілак- 
тичного мислення, успішному оволодінні найбільш поширеними методами та методиками гігієнічних досліджень, застосуванні гігієнічних знань для оптимізації лікарняного середовища та профілактики внутрішньолікарняних інфекцій. На жаль, у стоматології найбільш відчутним є великий перелік негативних виробничих чинників, їх поєднаний та комбінований вплив, серед яких: фізичні, хімічні, біологічні, психогенні чинники [3].

Навчальним планом викладання дисципліни “Гігієна та екологія” проводиться на другому році навчання. Важливим аспектом викладання профілактичної медицини є міжпредметна та внутрішньопредметна інтеграція. Гігієна та екологія як навчальна дисципліна базується на вивченні студентами медичної біології, медичної фізики, біологічної хімії, анатомії людини та фізіології. Вона тісно пов'язана із клінічними дисциплінами, що враховується при вивченні на другому курсі, у зв’язку з тим, що студенти ще не вивчали клініки. Застосування таких методичних прийомів при підготовці майбутнього лікарястоматолога дозволяють підняти його на якісно новий рівень профілактичного та клінічного мислення, здатного системно, комплексно вирішувати задачі лікарської практики на профілактичному та лікувальному рівнях.

За сучасними вимогами проведення практичних занять передбачає наявність трьох основних етапів: підготовчого, основного і заключного [4]. Важливу роль у професійному становленні майбутнього лікаря-стоматолога відіграє основний етап, оскільки саме на цьому етапі формується система профілактичного мислення. Для забезпечення даного етапу навчання розроблені задачі різних рівнів складності, алгоритм виконання практичних навичок.

Для успішного забезпечення навчального процесу співробітниками кафедри підготовлені необхідні матеріали методичного забезпечення занять. 3 цією метою розроблені тексти лекцій, які розкривають у повному обсязі проблемні питання відповідних розділів згідно з програмою. Викладання лекційного матеріалу супроводжується мультимедійною презентацією, що покращує сприйняття інформації. До кожного практичного заняття створені методичні вказівки з урахуванням необхідних моментів, що забезпечують педагогічно грамотну організацію навчального процесу на всіх його етапах [5]. У мето- дичних розробках для стоматологічного факультету врахована специфіка професійної підготовки майбутніх лікарів-стоматологів. Методичні матеріали складались з урахуванням усіх можливих форм і методів наукових розробок: зведених таблиць даних моніторингу, схем, графіків, малюнків. Крім того, теоретична частина методичних розробок насичена сучасними літературними даними як вітчизняної, так і світової літератури. Методичні рекомендації до практичних занять включають: навчальні цілі заняття, питання теоретичної підготовки, основну літературу для підготовки, викладення теоретичного матеріалу, навчальні практичні завдання, матеріали контролю рівня засвоєння теоретичних питань та практичних навиків. Організація навчального процесу здійснюється за кредитно-трансферною системою. Поточна навчальна діяльність студентів контролюється на кожному практичному занятті шляхом усного чи письмового опитування, вирішення задач. Програма дисципліни складається 3 одного підсумкового заняття, що здійснюється по завершенню вивчення дисципліни на останньому занятті. До підсумкового заняття допускаються студенти, які виконали всі види робіт, передбачені навчальною програмою, та за поточну успішність набрали кількість балів не меншу за мінімальну. Оцінка засвоєння проводиться на підсумковому занятті у вигляді комп’ютерного контролю, теоретичних питань, розв’язування задач та виконання практичних навичок.

Висновки: 1. Головною метою вивчення дисципліни є розвиток у студентів профілактичного мислення, використання його для оцінки рівня загального та стоматологічного здоров’ я, надання рекомендацій з гігієнічних питань здоровій та хворій людині.

2. Використання гігієнічних знань для оптимізації умов праці та лікарняного середовища, профілактика внутрішньолікарняної інфекції в лікувальнопрофілактичних закладах, у тому числі стоматологічного профілю.

3. Проведення у сфері діяльності лікаря-стоматолога санітарно-просвітницької роботи, яка спрямована на збереження й зміцнення загального та стоматологічного здоров’я.

Перспективою подальших досліджень є визначення мотивації студентів-стоматологів до професійної діяльності з метою формування у майбутніх лікарів високих професійних якостей. 


\section{Список літератури}

1. Бардов В. Г. Загальна гігієна та екологія. Навчальний посібник / В. Г. Бардов, І. В. Сергета. - Вінниця : Нова книга, 2002. - 216 с.

2. Налужна Т. В. Психологічна підготовка викладачів як умова гуманізації відносин викладач-студент / Т. В. Налужна // Медична освіта. - 2013. - № 3. - С. 67-70.

3. Охорона праці у медицині та фармації / В. М. Мороз, I. В. Сергета, Н. М. Фещук, М. П. Олійник. - Вінниця : Нова книга, 2005. - С. 271-296.
4. Кузьмінський А. І. Педагогіка вищої школи. Навчальний посібник / А. І. Кузьмінський. - К. : Знання, 2005. - 486 с.

5. Піскун Р. П. Організмовий рівень організації життя. Навчально-методичний посібник / Р. П. Піскун, Н. Г. Коломієць, А. А. Ващук. - Вінниця, 2008. - 186 с.

Отримано 14.05.15 